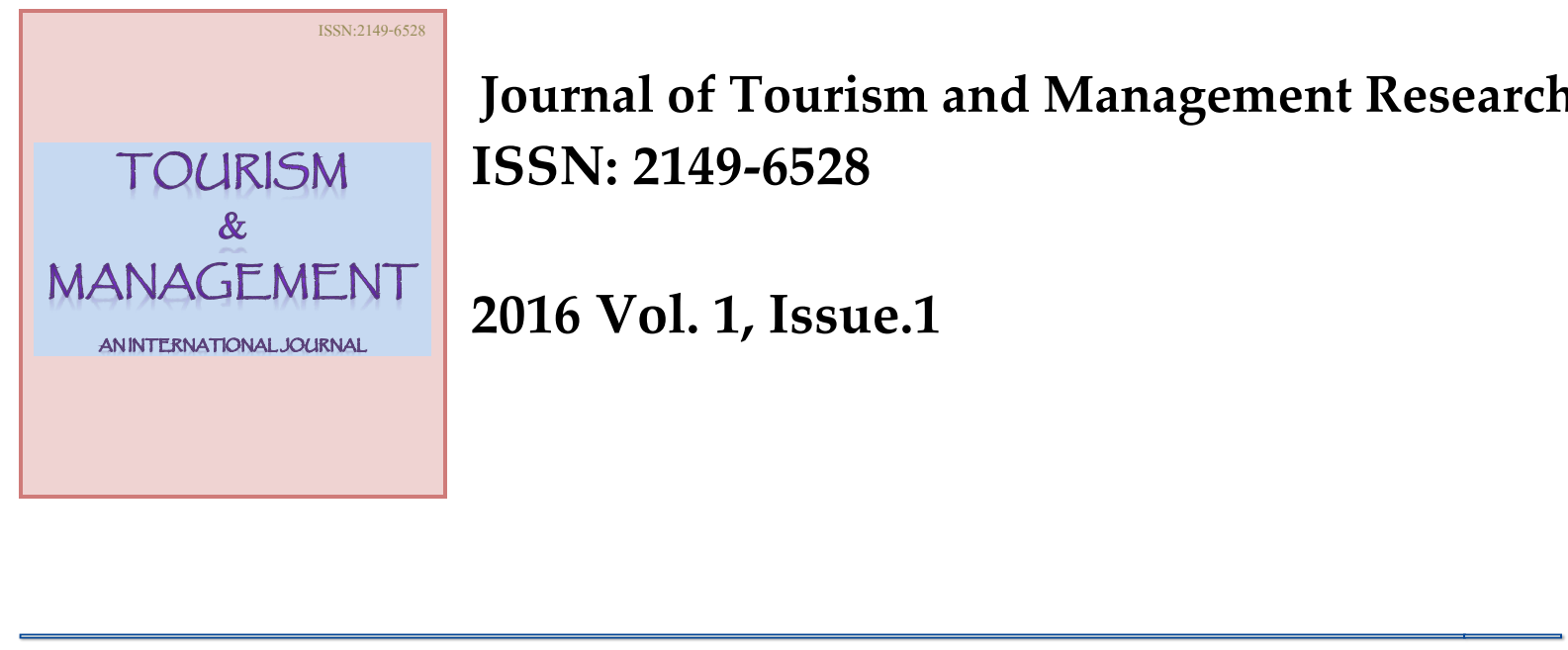

\title{
ANTECEDENTS OF E-SATISFACTION IN ONLINE RETAILING: A CONCEPTUAL FRAMEWORK
}

\begin{abstract}
The purpose of this study is to explore antecedents of e-satisfaction, specifically in e-retailing space and propose a theoretical framework to model e-satisfaction. This study is conceptual in nature, it analyses the current situation in Indian context based on secondary data collected from various researches, publications, reports etc. Through this review and analysis the author found that various dimensions of e-service quality like ease of use, convenience, product offerings and information, website design, system availability, e-fulfillment, efficiency, costeffectiveness, responsiveness, ease of contact and return are important antecedents of esatisfaction. Based on the review of literature a theoretical four factor model of e-satisfaction is proposed that consists of technology mediated factors, convenience, merchandising and after sales service. This study contributes to e-commerce literature by proposing a theoretical model of e-satisfaction that may be tested empirically in future to provide valuable insights to the marketers as well.
\end{abstract}

Keywords: E-commerce, E-Retailing, E-Satisfaction, E-Service Quality, E-Tailing.

Urooj Ahmad Siddiqui, Ph.D. Research Scholar. DRM, Babasaheb Bhimrao Ambedkar University, (A Central University), Lucknow, UP - 226025, India.

E-mail: urujuruj@gmail.com

Mohammad Shakeel Khan, PhD. Head/Coordinator - MBA Program, DRM, Babasaheb Bhimrao Ambedkar University, (A Central University), Lucknow, UP - 226025, India.

E-mail: shakeeldrm@gmail.com 


\section{Introduction}

Technology is fast changing the traditional way of retailing from physical retail stores to technology enabled online retail websites. Customers especially the generation next (age group 18-36 yrs.) are swiftly adopting the online channels to buy a variety of products ranging from consumer durables to apparel and accessories to day to day groceries. This adoption of the online channels is driving fast growth in the E-retailing market. To get a pie in the cake the competition is also neck to neck between the national players and this competition is escalated by the international giants joining the bandwagon in Indian online selling market. The tough competition has increased interest of both online marketing professionals and academicians towards consumer satisfaction and loyalty for Internet Retailing Websites (ERetailing) and this may be justified by sheer size of the revenue generated in the last 2-3 years and opportunities presented by this fast-growing channel for retailing. Therefore it becomes imperative to study antecedents or factors affecting customer satisfaction (E-satisfaction) in E-Retailing. This increasing interest has generated a lot of research in this domain but there is dearth of studies in Indian context. This study tries to study the E-satisfaction in Indian context and generate information for further studies. E-Business refers to electronic means to conduct a company's business. E-Commerce is a more general term which means that the company or its website offers to transact or facilitate the selling of products or services online (Kotler et al., 2009). E-Commerce in turn has given rise to E-Marketing, E-Purchasing, ESelling. E-Marketing refers to company's efforts to inform communicate, promote and sell products and services over the internet. Similarly E-Purchasing means companies decide to purchase goods, services or information from various online suppliers. This study specifically evaluates the online selling of products and services that is called as 'Online Retailing' or 'ERetailing' or for that matter 'E-Tailing' through third party web portals. Similarly as per ecommerce and marketing literature we can define term E-customer as "an individual or corporate one who are using e-portals to purchase, ordering, receiving information and paying price / charges of services/product purchased through various types of e-channels" i.e. internet, e-mail, personal computer, ATM, POS, credit cards, debit cards, cell phone, fax, phone and other electronic devices (Kumbhkar, 2012). This study defines E-Customer as "an individual who is using internet or third party web portals to purchase products for personal consumption and/or receiving information regarding products and its prices through devices like personal computer (desktop and laptops) or various handheld devices (tabs and smart phones)".

In the last two decades technology mediated commerce specifically e-retailing has been a preferred topic among marketing researchers worldwide. Extensive research has been done in various domains of e-retailing, may it be service quality, trust, perceived value, satisfaction or loyalty there exist a plethora of studies. As discussed in this study, the phenomenal growth witnessed by Indian e-commerce sector is fuelled by online retailing, and along with this growth competition is also growing thick and fast. Owing to this cut throat competition eretailers are finding it tough to maintain their customers' base. In this tough competitive environment it becomes important for the retailers to find and practice distinct strategies to satisfy their customers to the extent that they are not affected by the competition.

Against this backdrop, it becomes imperative to study and research e-retailing domain in Indian context where there is a dearth of studies that may provide crucial insights to marketing professional. Most of the studies and models of satisfaction and loyalty have been proposed and tested outside India. The results of these studies could not just be applied as it is, to Indian context because Indian market is different with respect to their buying characteristics. So there is a need of research in different domains of online retailing India. This study tries to fulfill this need to some extent. First of all, this study elaborates the basics of e-commerce and e-retailing to analyse the current situation in Indian context and 
understands the concept of satisfaction in e-retailing. Secondly, it tries to review the available literature to explore and investigate the different models and antecedents of e-satisfaction and proposes a conceptual model. This study tries to contribute to the e-retailing literature by providing the extant knowledge in the domain of satisfaction in e-retailing and proposes a theoretical framework to model e-satisfaction. The proposed model may be tested in future in Indian context to provide insights to the marketing professionals as well. The particular objectives of this study are:

1. To understand the concept of E-satisfaction in online selling space.

2. To review the literature related to the antecedents of the E-satisfaction.

3. To conceptualize a theoretical framework for the antecedents of E-satisfaction.

\section{Literature Review}

\subsection{E-Tailing in India - A Brief Review}

Online Retailing or E-tailing is part of overall e-commerce market which spreads from online ticketing to online deals, financial services and specifically retailing through internet websites. The below figure shows the standing of E-tailing among other e-commerce categories:

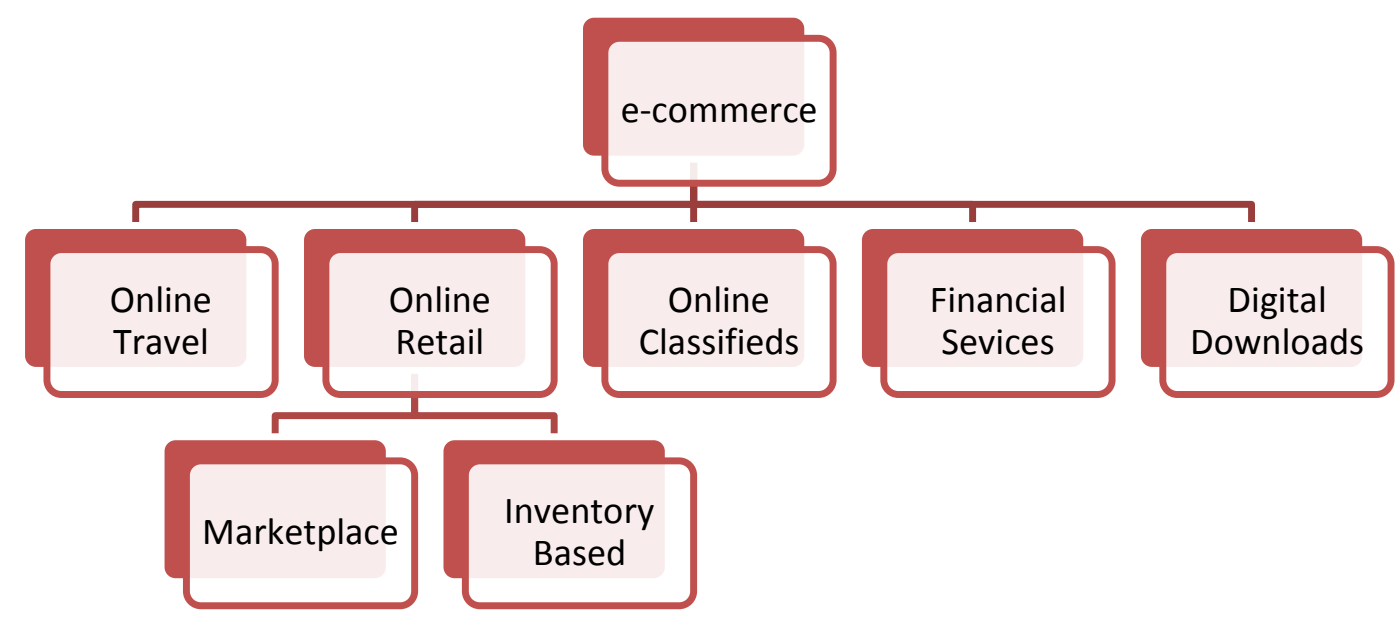

Figure 1: E-commerce Classification.

Source: Deloitte and ASSOCHAM study on Indian Online Retailing.

In a joint research paper by Deloitte and ASSOCHAM (2015) the online B2C market is being divided as market Marketplace business model and Inventory based model. It defines online retailing companies as a part of e-commerce companies particularly those in the primary business of providing web platform(s) and website(s) through which individuals, using a computer or smart phone, can purchase a product or service. The definition excludes online travel, online classified, online financial services and digital downloads.

In terms of size India's online retail industry has grown at a swift pace in the last 5 years. According to $\mathrm{PwC}$ it has grown from around 0.4 billion USD revenues in 2009 to 3.5 billion USD in 2014, translating into a compounded annual growth rate (CAGR) of over34 per cent. The 7-fold growth came on the back of increasing internet penetration and changing lifestyles, primarily driven by books, electronics and apparel. IAMAI and CRISIL Research expects the buoyant trend to sustain in the medium term, and estimates the market will grow at a healthy near to 50 per cent CAGR to 6 billion USD by 2015 . 


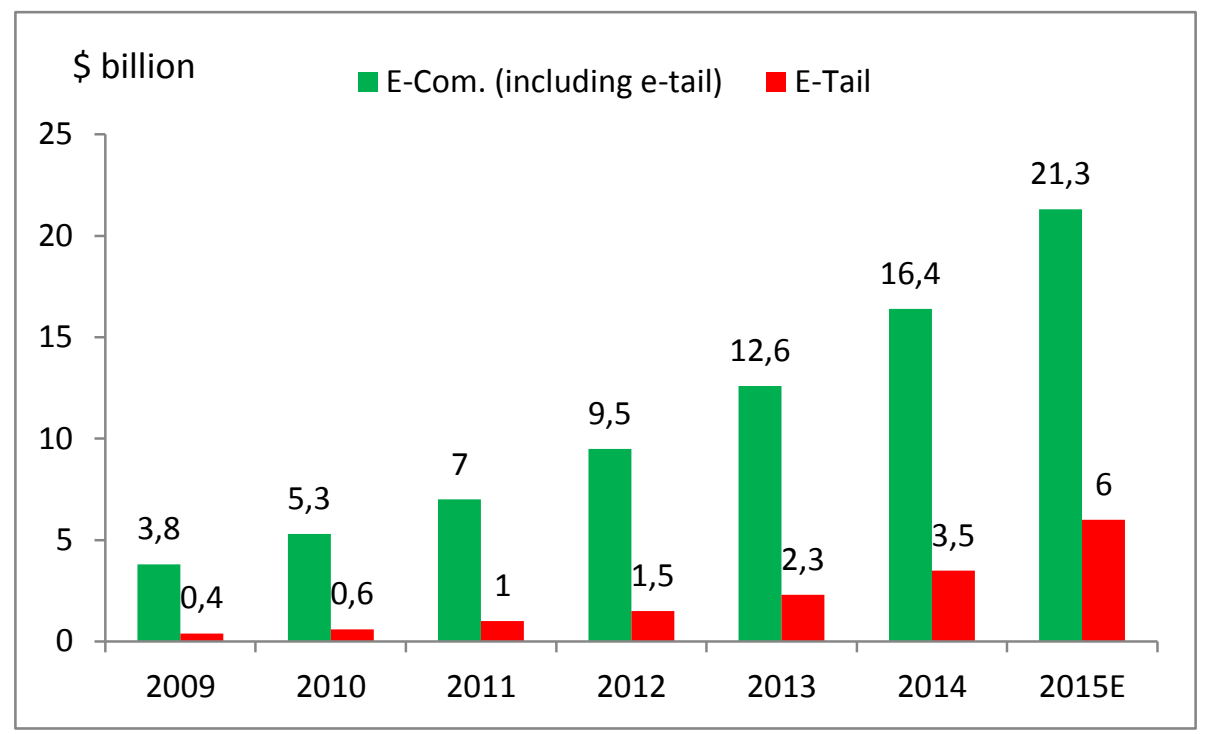

Figure 2: Online Retail Market Size and Growth. Source: PwC India (IAMAI, CRISIL and PwC Research).

The entry of new players in niche segments such as grocery, jewellery and furniture, along with large investments by existing players in the apparel and electronics verticals, will be the drivers. In terms of size, India's online retail industry is very small compared with both organised and overall (organised + unorganised) retail in the country. According to CRISIL Research in 2012-13 the size of overall market in India was staggering Rs. 25,286 billion. The organized retailing amounts Rs. 1,726 billion which is only $7 \%$ of overall market size. The size of online retailing is Rs. 139 billion that is very small as compared to overall market size. It is $7.9 \%$ of the total organized market whereas a meager 0.5 of the total market. This shows how much potential it has given in the current situation.

Online retailing is growing in India the competition is also growing with leaps and bounds. As every coin has two sides, there are some challenges along with growth opportunities in e-retailing. One of the most immediate challenges faced by the industry in India is that of competition. Indian e-taling industry is getting extremely competitive as the competition is multifaceted. They not only face competition from other e-tailers but also from traditional brick-and-mortar formats and this competition is not only from Indian firms but also from international players. Siddiqui and Khan (2014) have described the completion in Indian context through table 1.

Table 1: Competition in India's E-Retailing Segment.

\begin{tabular}{|l|l|l|}
\hline & Brick-n-mortar & E-tailers \\
\hline \multirow{3}{*}{$\begin{array}{l}\text { National } \\
\text { Competitors }\end{array}$} & $\begin{array}{l}\text { Big Bazaar, Reliance Retail, Pantaloon, } \\
\text { Shoppers Stop, Spencer's, Birla More, } \\
\text { Bharti's Easyday, Food Bazaar, Tata's } \\
\text { Trent etc. }\end{array}$ & $\begin{array}{l}\text { Flipkart, Snapdeal, Jabong, Yebhi, } \\
\text { IndiatimesShopping, Home Shop } 18 \\
\text { etc. }\end{array}$ \\
\end{tabular}




\begin{tabular}{|l|l|l|}
\hline $\begin{array}{l}\text { International } \\
\text { Players }\end{array}$ & $\begin{array}{l}\text { All Single Brand Retailers of Apparels, } \\
\text { Consumer Durables, Mobiles Computers } \\
\text { etc. Like Marks \& Spencer, Levi's, Nike } \\
\text { Samsung, HP, Sony etc. }\end{array}$ & e-Bay, Amazon \\
\hline
\end{tabular}

Source: Siddiqui and Khan (2014).

With more than ten Mass Merchants and hundreds of Vertical Merchant there is heavy completion within e-tailing format and not to mention already existing organized physical retailers like Big Bazaar, Pantaloons, Spencers, V-Mart etc. Adding to this neck-to-neck competition the international players are also not far behind. With government's decision to allow 51\% FDI in multi-brand $\mathrm{B} 2 \mathrm{C}$ retailing, international giants have also joined the bandwagon.

\section{Methodology}

As the objective of the study is to understand the concept of E-satisfaction and review the literature to bring out a theoretical framework for the antecedents of E-satisfaction, the study is based on different literature available in the domain E-satisfaction and E-loyalty. Various research papers have been collected from trusted publications through internet and different reports have been reviewed from a variety of sources like various publications of the government; various publications of national and international research organizations; books and newspapers; reports and publications of various associations connected telecommunication (mobile and internet) department. Content Analysis of various available literatures (research papers and reports) has been done using the techniques of statistical compilations, manipulations, and referencing. Hence this study is based on Qualitative Analysis of the available literature that is the secondary data.

\section{Conceptual Framework}

Owing to the intense competition it becomes imperative for E-Retailers to satisfy their customers to the extent of customer delight and maintain a strong customer relationship so that they can make loyal customers. Anderson et al. (1994) showed that there is a strong positive relationship between customer satisfaction and firm profits. Bolton \& Lemon (as cited in Yang \& Peterson, 2004) stated that satisfied customers tend to have a higher usage of service and in contrast to the ones who are not satisfied. And according to Zeithaml et al. (1996) satisfied consumers are more likely to have greater repurchase intent and to recommend products and/or services to their acquaintances Winer (2001), while developing an extensive framework for customer relationship management in e-commerce space granted crucial attention to customer satisfaction, recommended regular measurement and monitoring of customer satisfaction so that appropriate programs could be developed from time to time for delivering value that exceeds customer expectation. Bhattacherjee (2001) stated that customer centric approach is very important in e-commerce B2C space where completion is just a click away and emphasized customer satisfaction as a part this approach because satisfied customers may advertise via positive word-of-mouth which less expensive (than print or any mass media) and more efficient channel due to more trust associated with word of mouth. Therefore the vital role of satisfaction for better customer relationship and loyalty appears to remain intact even in E-commerce settings.

The concept of satisfaction has been discussed extensively in the services and traditional retailing literature (Anderson et al., 1994; Oliver, 1981; Oliver, 1997; Oliver, 1999; Parasuraman, et al., 1988; Zeithaml et al., 1996). Traditionally the level of customer satisfaction is determined by the service environment, quality of services, price and 
purchasing process. The definition of Customer satisfaction in offline context has been given as 'an affective reaction in response to a single or series of cognitive service encounters.' Oliver (1997) described customer satisfaction as customers' evaluation of a product or service with regard to their needs and expectations. Anderson and Srinivasan (2003) defined E-sat as "the contentment of the customer with respect to his or her prior purchasing experience with a given E-commerce firm". According to Oliver (1997) satisfaction is the "consumer's fulfilment response" and hence according to him a satisfaction judgment, involves at the minimum two stimuli-an outcome and a comparison referent."

Building on this concept Szymanski and Hise (2000) conceptualized satisfaction in online context as E-Satisfaction (henceforth referred as E-SAT) as the consumers' judgment of their Internet retail experience as compared to their experiences with traditional retail stores. They defined e-satisfaction in the online context as an overall construct reflecting the cumulative effect of a set of discrete experiences with the service provider over a period of time. Their model can be represented in figure 3 .

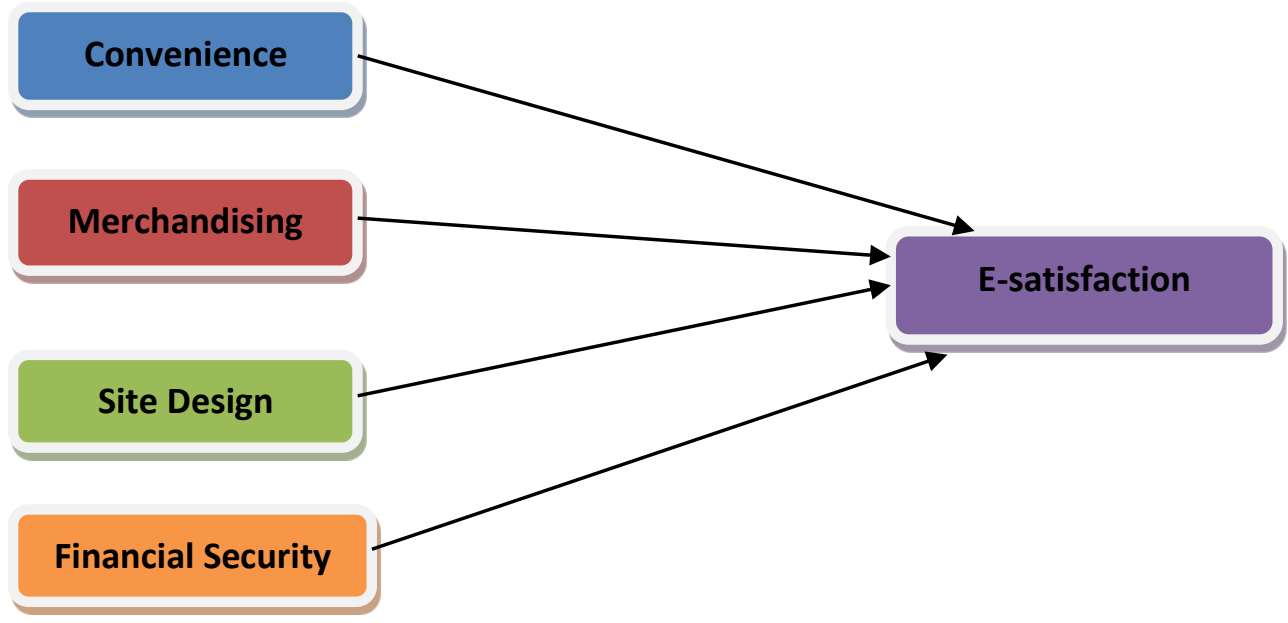

Figure 3: Szymanski and Hise (2000) Model.

This is one of the most basic models of E-Satisfaction. Szymanski and Hise (2000) explored the drivers of e-Sat in e-com settings. Initial focus group interviews with online shoppers suggested that e-satisfaction was the outcome of online shopping convenience, merchandising (product information and product offerings), site design, and financial security (Szymanski \& Hise, 2000). They developed measures for these key constructs and tested them using an online sample of 1,007 respondents in US, finding that all five drivers of e-satisfaction had positive effects on e-satisfaction, and all excepts product offerings had a significant impact on e-satisfaction. Similar results were also obtained in a different context by Burke (2002), who found that online shoppers were most satisfied with the convenience, product quality, value provided, and product selection offered by the online shopping experience. Evanschitzky et al. (2004) replicated the above model in Germany and found the same results that all five drivers of e-satisfaction had positive effects on e-satisfaction, and all except product information had a significant impact on e-satisfaction. They did this study using an online sample of 351 (questionnaire was sent to 2000 people online).

Wang and Huarng (2004) have argued that e-satisfaction is influenced by nine distinct consumer perceptions--Web design, price, promotion, merchandise availability, on-time 
delivery, met expectations, return policy, customer service and order tracking. These nine perceptions occur in two purchase phases: pre-order and post-order. Schaupp and Bélanger (2005) conducted a study using a conjoint analysis of consumer preferences based on data collected from 188 young consumers. Results indicate that the three most important attributes to consumers for online satisfaction are privacy (technology factor), merchandising (product factor), and convenience (shopping factor). These are followed by trust, delivery, usability, product customization, product quality, and security. It was concluded that the three most important attributes for online consumers satisfaction are technology factor (Privacy, Usability, Site Design and Privacy), Shopping Factors (Convenience, usability, Trust and Trustworthiness Delivery), and Product Factors (Merchandising, product quality, Product Value and Product Customization).

Liu et al. (2008) examined the antecedents of customer satisfaction in online shopping in China, with nine antecedents, divided based on the stage of purchase: the quality of information, site design, and a variety of products at the stage of information and alternatives seeking; transaction capabilities, site response, security/privacy, and payment system in the execution phase of purchase, as well as management and customer service delivery at the post-purchase. Yoon and Ha (2008) analyzed movie related website service and its influence on e-customer satisfaction. In their study they have used Information Factor, Convenience Factor, Technology Factor, Community Factor, Entertainment Factor, Price Factor and Brand Name Factor to assessed e-satisfaction of the users.

According to Taylor and Hunter (2003) e-satisfaction is generally defined as pleasurable fulfillment and it is based on technology-mediated marketing relationships. It is unique from other closely related concepts such as e-service quality (Parasuraman et al., 2005; Zeithaml et al., 2002). Taylor and Hunter (2003) mentioned that e-satisfaction is closely related to value judgment, brand attitude, trust, and resistance to change. Schefter and Reichheld (2000) argued that, "e-satisfaction is attitude of the customers about quality and it includes customer support, on-time delivery, compelling product presentations, convenient and reasonably priced shipping and handling, and clear and trustworthy privacy policies."

All the above discussed studies laid emphasis on drivers or antecedents of e-satisfaction. There are several studies where e-loyalty has also been discussed along with satisfaction. Some studies like Marcel et al. (2001) and Srinivasan and Anderson (2002) have directly modeled the antecedents of e-loyalty (not considering the e-satisfaction). As per study conducted by Marcel et al. (2001), e-customers loyalty depends up on Website \& Technology (Speed, easiness, Personalized features, Design, Language, Search Option, Server reliability, Content, Quick shopping checkout), Value Proposition (Customized products, Large set of choices, Product quality, Guarantees, Well-known brands, Pricing), Brand Building (Brand image, Brand Community) Customer Service (Fast response to customer inquiries, Easy to contact, Free online applications, Easy payment methods, Fast delivery, Delivery options, Customer reward system), Trust \& Security (Trust, Third party approval, Privacy, Reputation, Reliability, Authentication and Non-repudiation). Srinivasan and Anderson (2002) studied the causes and consequences of online customer loyalty in online business-to-consumer (B2C) context. They proposed and tested 8C model consisting of customization, contact interactivity, cultivation, care, community, choice, convenience, and character. The effect of all the factors except convenience was found significant on online customer loyalty.

Generally it is considered that satisfaction leads to loyalty but the relationship is affected by other factors (Oliver, 1999). The effect of different factors on this relationship has been studied in various researches in diverse contexts. Anderson and Srinivasan (2003) proposed a contingency framework for the relationship between e-sat and e-loyalty in e-commerce context shown in the figure 4.

\section{Original Scientific Paper}

Siddiqui, U.A. and Khan, M.S.

Vol.1/No.1/2016/155-165. DOI:10.26465/ojtmr.2016132261 


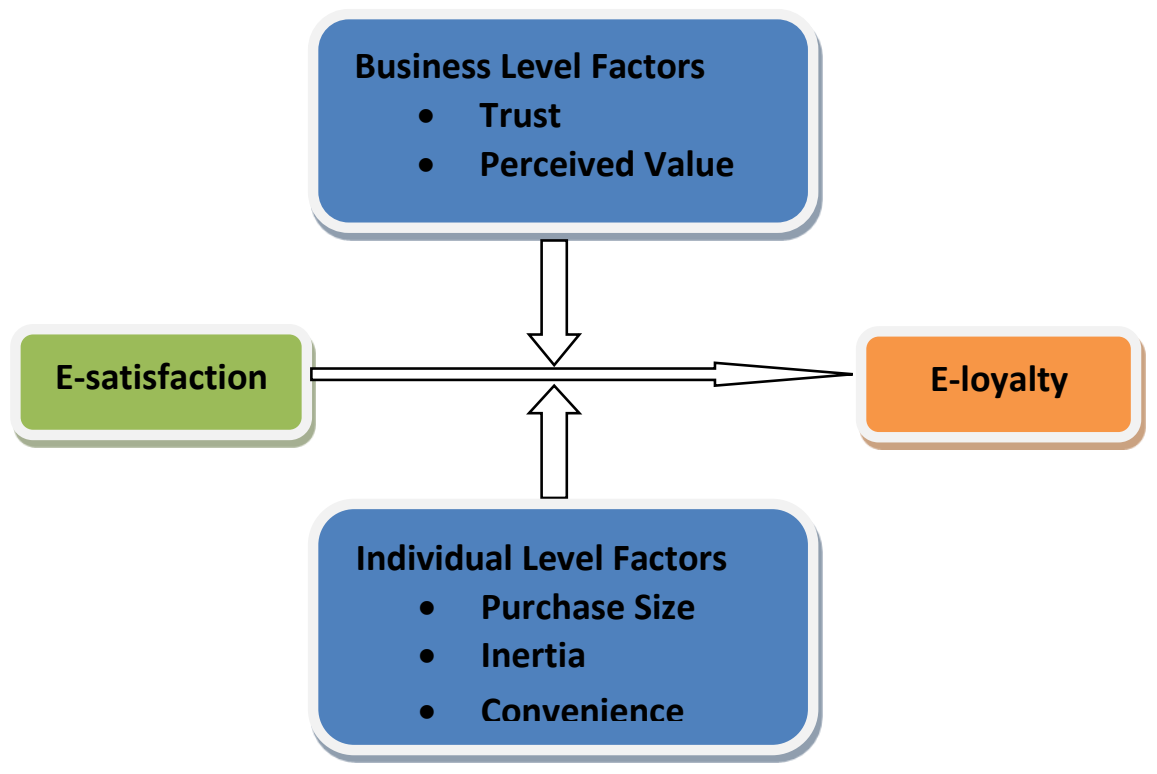

Figure 4: Anderson and Srinivasan (2003) Model.

Anderson and Srinivasan (2003) defined e-sat as "the contentment of the customer with respect to his or her prior purchasing experience with a given e-commerce firm". Thus, e-SAT can be construed as a summary overall construct reflecting the customer post-purchase level of contentment with the experience with the e-service. Though the definition given in this study is widely used and accepted definition of satisfaction in e-service settings this study is not about the drivers or antecedents of e-sat. It is more about the consequences of e-sat with focus on its relationship with e-loyalty and the effect of moderating variables on the relationship. It could best be stated as moderating effect of e-satisfaction on e-loyalty. All the moderating variables were found to have significant effect on the relationship between e-sat and e-loyalty except Convenience Motivation. According to Anderson (2003) "Typically, esatisfaction has been assumed to be a natural antecedent to e-loyalty".

This research reveals that the impact of e-satisfaction on e-loyalty can be significantly moderated by individual level variables (inertia, convenience motivation, and purchase size) and company level variables (trust and perceived value). Chang \& Wang (2011) conducted research on online customer satisfaction (e-satisfaction) and online loyalty and found significant influence of e-service quality and perceived value while Gera (2011) modeled eservice quality and perceived value on customer satisfaction online (e-satisfaction) and customer loyalty online (e-loyalty) using structural equation modeling (SEM). In his research Gera (2011) examined the role of mediating variables using path analysis. Similar study was done by Chen (2012) in e-service settings which found a significant mediating effect of involvement, trust, perceived value and commitment.

\section{Conclusions}

By far the most discussed and accepted definition of e-satisfaction is that of Anderson and Srinivasan (2003) i.e. "the contentment of the customer with respect to his or her prior purchasing experience with a given e-commerce firm". This study also accepts this definition. As far as the antecedents of E-satisfaction are concerned, the proposed framework gives them in a nut shell. Through the qualitative analysis of the literature reviewed, the antecedents of Esatisfaction may be classified basically into two categories represented by technology mediated factors and the factors related to the product. Technology and Product/Convenience 
factors may further be classified basically at three stages of online purchase i.e. Pre purchase, Purchase stage and Post purchase stage. The key dimensions could be best understood through the matrix presented in table 2. Although all the factors are not exclusive and not even exclusive to one category they represent a good picture how e-satisfaction is viewed in literature. These factors may be considered as most important to assess the customers' satisfaction in e-Retailing settings.

Table 2: Classification of Antecedents of E-satisfaction.

\begin{tabular}{|c|c|c|c|}
\hline & Pre Purchase Stage & Purchase Stage & Post Purchase Stage \\
\hline $\begin{array}{l}\text { Technology } \\
\text { Factors }\end{array}$ & $\begin{array}{l}\text { Website Design } \\
\text { Usability, Ease of Use/Surfing } \\
\text { Information Content Search } \\
\text { Options } \\
\text { Website Speed } \\
\text { Server Reliability } \\
\text { Customer Inquiries } \\
\text { Website Response }\end{array}$ & $\begin{array}{l}\text { Financial Security/Privacy } \\
\text { Easy Payment System, } \\
\text { Channels, Options } \\
\text { Information Reliability }\end{array}$ & $\begin{array}{l}\text { Customer service } \\
\text { Order tracking } \\
\text { Ease of Contact } \\
\text { Ease of Return }\end{array}$ \\
\hline $\begin{array}{l}\text { Product and } \\
\text { Convenience } \\
\text { Factors }\end{array}$ & $\begin{array}{l}\text { Product Offerings } \\
\text { Product Information } \\
\text { Product Variety/Assortment } \\
\text { Recreation/Entertainment } \\
\text { Personalized/Customized } \\
\text { Features }\end{array}$ & $\begin{array}{l}\text { Value Provided } \\
\text { Trust \& Security } \\
\text { Convenience of Time } \\
\text { Convenience of Place } \\
\text { Payment Convenience }\end{array}$ & $\begin{array}{l}\text { Trustworthiness } \\
\text { Delivery } \\
\text { On Time/Fast Delivery } \\
\text { Met Expectation } \\
\text { Return Policy } \\
\text { Delivery Options }\end{array}$ \\
\hline
\end{tabular}

Owing to the plethora of factors contributing to the satisfaction and in accordance with the available literature the dimensions which create customer satisfaction or contentment with the prior purchasing experience are different combination of basically four major factors: Technology mediated factors, Merchandising, Convenience and After sales services. Technology in itself is not a factor directly affecting but it manifests itself through E-Service Quality and Financial Aspects. E-Service Quality is a complex concept to understand but is a major factor contributing to E-satisfaction. Financial aspects involve all the factors discussed above. Merchandising and Convenience are according to the literature consisting of product offerings, ease of use, convenience of time and place. whereas after sales service includes order tracking, proper delivery, return etc. which is also a complex process and needs to be studied in detail. Accordingly the proposed conceptual framework is: 


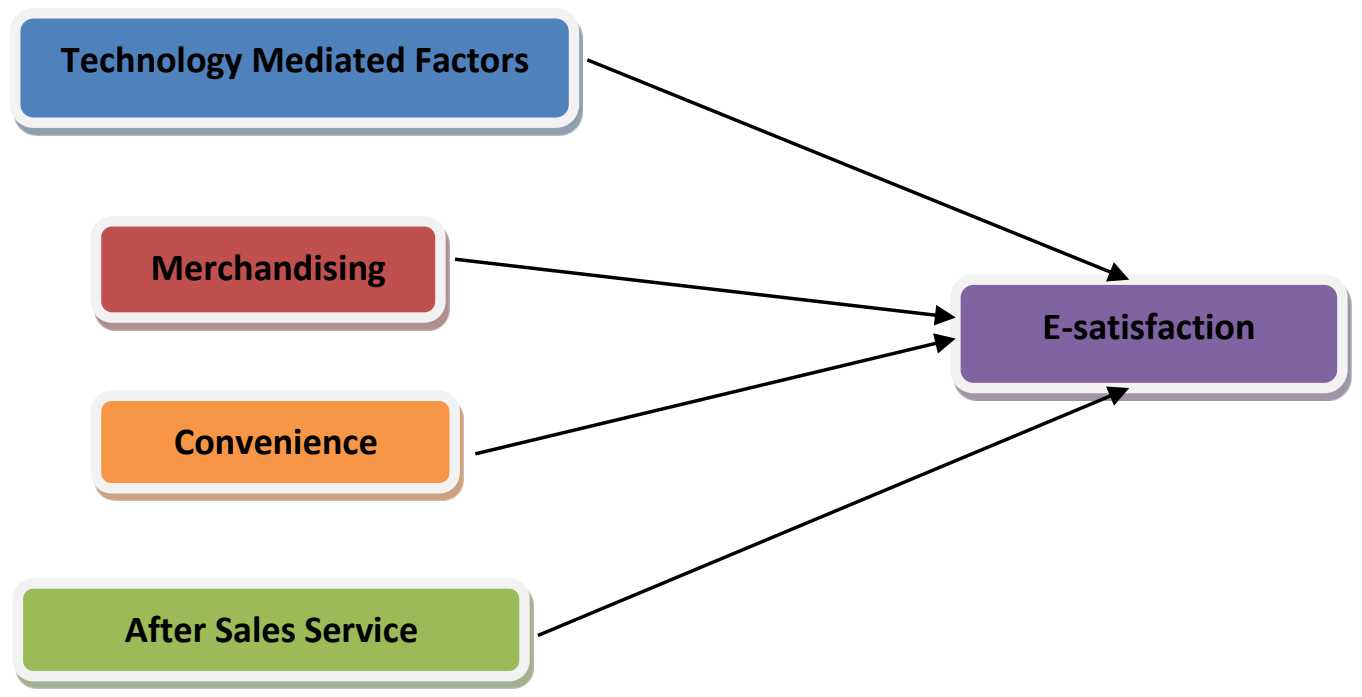

Figure 5: Conceptual Framework for E-Satisfaction.

This is a proposed conceptual model based on the literature review. The model may be tested empirically in future by selecting different dimensions of each factor to provide useful insights for the marketing professionals. The model may serve as a guideline for further research.

\section{References}

Anderson, E. W., Fornell, C., and Lehmann, D. R. (1994). Customer satisfaction, market share, and profitability: Findings from Sweden. Journal of Marketing, 58, 53-66.

Anderson, R. E., and Srinivasan, S. S. (2003). E-satisfaction and e-loyalty: A contingency framework. Psychology and Marketing, 20(2), 123-138.

Bhattacherjee, A. (2001). An empirical analysis of the antecedents of electronic commerce service continuance. Decision Support Systems, 32, 201-214.

Burke, R. R. (2002). Technology and the customer interface: What consumers want in the physical and virtual store. Journal of the Academy of Marketing Science, 30(Fall), 411432.

Chang, H. H., and Wang, H. (2011). The moderating effect of customer perceived value on online shopping behavior. Online Information Review, 35(3), 333-359.

Chen, S.C. (2012). The customer satisfaction-loyalty relation in an interactive e-service setting: The mediators. Journal of Retailing and Consumer Services, 19(2012), 202-210.

Crisil Research. (2014, Feb.). Crisil Opinion, e-tails eats into retail. Retrieved from http://www.crisil.com/pdf/research/CRISIL-Research-Article-Online-Retail-Feb14.pdf.

Deloitte and ASSOCHAM, (2014). Future of e-Commerce: Uncovering Innovation. Retrieved from http://www.deloitte.com/in.

Evanschitzky, H., Iyer, G.R., Hesse, J., and Ahlert, D. (2004). E-satisfaction: a reexamination. Journal of Retailing, 80, 239-247. 
Gera, R. (2011). Modelling e-service quality and its consequences in India: an SEM approach. Journal of Research in Interactive Marketing, 5 (2/3), 203-225.

Kotler, P., Keller, K. L., Koshy, A. and Jha, M. (2009). Marketing Management: A South Asian Perspective (13 ${ }^{\text {th }}$ Ed.). New Delhi, India: Pearson Education US.

Kumbhkar, V.M. (2012). Conceptualisation of E-Services Quality and E-Satisfaction: A review of Literature. Journal of Management Research and Practice, 4(4), 12-18.

Liu, X., He, M., Gao, F., and Xie, P. (2008). An empirical study of online shopping customer satisfaction in China: a holistic perspective. International Journal of Retail \& Distribution Management, 36(11), 919-940.

Marcel, G., Krishnan, K. S., and Scheffold, K.B. (2001). From Brand Loyalty to E-Loyalty: A Conceptual Framework. Journal of Economic and Social Research, 3(1), 43-58.

Oliver, R. L. (1981). Measurement and evaluation of satisfaction processes in retail settings. Journal of Retailing, 57, 25-48.

Oliver, R. L. (1997). Satisfaction: A behavioral perspective on the consumer. [e-book]. Retrieved from http://books.google.com.

Oliver, R.L. (1999). Whence consumer loyalty? Journal of Marketing, 63(Special Issue), 3344.

Parasuraman, A., Zeithaml, V. A., and Berry, L. L. (1988). SERVQUAL: A multi-item scale for measuring consumer perception of service quality. Journal of Retailing, 64(1), 12-40.

Parasuraman, A., Zeithaml V. A., and Malhotra A. (2005). E-S-QUAL: A Multiple-Item Scale for Assessing Electronic Service Quality. Journal of Service Research, 7(X), 1-21.

PwC India. (2015, Feb.). e-Commerce in India: Accelerating growth. Retrieved from http://www.pwc.in.

Schaupp, L. C., and Bélanger, F. (2005). A Conjoint Analysis of Online Consumer Satisfaction. Journal of Electronic Commerce Research, 6(2), 95-111.

Schefter, P., and Reichheld, F. (2000). E-Loyalty. Harvard Business Review, 78(4), 105-114.

Siddiqui, U. A., and Khan, M. S. (2014). E-Tailing in India: Prospects and Challenges. In G. Nathand N. Gera ( Eds.), Managing Organizations of Tomorrow by Capitalizing Generation Next ( $1^{\text {st }}$ ed., pp. 159-172). New Delhi, India: BVIMR.

Srinivasan, S. S., and Anderson, R. E. (2002). Customer Loyalty in e-commerce: an exploration of its antecedents and consequences. Journal of Retailing, 78, 41-50.

Szymanski, D.M., and Hise, R.T. (2000). e-Satisfaction: An Initial Examination. Journal of Retailing,76(3), 309-322.

Taylor, S. A., and Hunter, G. (2003). An Exploratory Investigation Into the Antecedents of Satisfaction, Brand Attitude and Loyalty Within the (B2B) eCRM Industry. Journal of Customer Satisfaction, Dissatisfaction and Completing Behavior, 16(2003), 19-35.

Wang, M., and Huarng, A. S. (2004). Determinants of e-satisfaction in pre-order and postorder phases. Journal of Academy of Business and Economics, 4(1), 8-21.

Winer, R. S. (2001). A framework for customer relationship management. California Management Review, 43, 89-105.

Yang, Z., and Peterson, R. T. (2004). Customer perceived value, satisfaction, and loyalty: The role of switching costs. Psychology and Marketing, 21(10), 799-822.

Yoon, C., and Ha, J. (2008). Users' Attitudes Toward Movie-Related Websites And ESatisfaction. Journal Of Business Economics Research, 2(3), 13-28.

Zeithaml, V. A., Berry, L. L., and Parasuraman, A. (1996). The Behavioral Consequences of Service Quality. Journal of Marketing, 60(April), 31-46.

Zeithaml V. A., Parasurarnan A., and Malhotra A. (2002). Service Quality Delivery Through Web Sites: A Critical Review of Extant Knowledge. Journal of the Academy of Marketing Science, 30(4), 362-375. 